\title{
Vybrané (meritorní) aspekty soudního přezkumu komunálních voleb 2018
}

\section{Municipal Elections 2018 - Selected (Substantive) Issues}

\author{
Jan Ferfecký, Jan Scheuer ${ }^{* *}$, Josef Šíp ${ }^{* * *}$
}

\begin{abstract}
Abstrakt
Clánek se zabývá analýzou soudního prezkeumu voleb do obecnich zastupitelstev v roce 2018 napríc jednotivými krajskými soudy. Soustredi se predevšim na samotnou podstatu volebního prezkumu voleb prezkum vísledki voleb, priběbu blasováni a vedeni volebni kampaně. Diskutovány jsou tak predevšim otárky, na základě jakých skutečností pristoupi soudy k problášeni neplatnosti volby kandidátalü, neplatnosti hlasováni č neplatnosti voleb jako celku. K tomu bylo nezbytné rozebrat otázku dokazováni ve volebnim soudnictví, existenci zuläśt významné indicie, charakterizovat také roli volebni komise pro soudni prezkeum voleb ř vymezit pojem volebni kampaň a jeji nálę̌itosti.
\end{abstract}

\section{Klíčová slova}

Soudni prezkeum voleb; neplatnost voleb; neplatnost blasováni; neplatnost volby kandidáta/ $\stackrel{u}{\text {. }}$

\begin{abstract}
Authors of the article analyze complete case law of all regional courts concerning municipal elections 2018. They focus mainly on the very essence of the judicial review of elections - review of election results, voting and campaigning.
\end{abstract}

\section{Keywords}

Judicial Review of Elections; Invalidity of Elections; Invalidity of the Vote; Invalidity of the Candidate's Election.

\section{Úvod}

V př́spěvku se věnujeme soudnímu přezkumu výsledků voleb, průběhu hlasování a vedení volební kampaně. Naší hlavní motivací pro sepsání tohoto př́íspěvku bylo zmapovat

\footnotetext{
* Mgr. Bc. Jan Ferfecký, doktorand, Katedra správní vědy a správního práva, Právnická fakulta, Masarykova univerzita, Brno; soudce, Městský soud v Praze / Ph.D. student, Department of Administrative Studies and Administrative Law, Faculty of Law, Masaryk University, Brno, Czech Republic; Judge, Municipal Court, Prague, Czech Republic / E-mail: 348229@mail.muni.cz

** Mgr. Jan Scheuer, doktorand, Katedra správní vědy a správního práva, Právnická fakulta, Masarykova univerzita, Brno; asistent soudkyně, Krajský soud v Brně / Ph.D. student, Department of Administrative Studies and Administrative Law, Faculty of Law, Masaryk University, Brno, Czech Republic; Legal Assistant, Regional Court in Brno, Czech Republic / E-mail: 370659@mail.muni.cz

*** Ing. Mgr. et Mgr. Josef Š́p, doktorand, Katedra ústavního práva a politologie, Právnická fakulta, Masarykova univerzita, Brno; asistent soudkyně, Krajský soud v Brně / Ph.D. student, Department of Constitutional Law and Political Science, Faculty of Law, Masaryk University, Brno, Czech Republic; Legal Assistant, Regional Court in Brno, Czech Republic / E-mail: 393112@mail.muni.cz
} 
přístup krajských soudů zejména k věcným otázkám soudního přezkumu komunálních voleb ${ }^{1}$ a upozornit na možné rozdíly a také problematické aspekty $\mathrm{v}$ jejich príistupu. K naplnění tohoto výzkumného cíle jsme analyzovali volební judikaturu krajských soudů týkající se komunálních voleb 2018 (v daném roce bylo podáno 239 návrhů). ${ }^{2}$

Nejprve představíme základní výsledky našeho výzkumu z pohledu celkové úspěšnosti návrhů a stručně přiblížíme legislativní a judikatorní východiska přezkumu komunálních voleb $^{3}$; speciální pozornost zde bude věnována též otázce ústního jednání a na něm probíhajícímu dokazování. Z hlediska věcného přezkumu se v našem článku zaměřujeme na několik dílčích aspektů. Předně jde o problematiku tzv. zvlášt’ významné indicie, toho, kdy její existence byla shledána a kdy nikoliv, a jejího významu pro následný přepočet hlasů. To ostatně bude další podstatná část tohoto článku, nebot' otázka toho, za jaké situace krajské soudy prristoupily $\mathrm{k}$ přepočtu hlasů a jakým způsobem tak učinily, je jedním ze stěžejních problémů přezkumu (nejen) obecních voleb 2018. Dále se blíže věnujeme návrhům na neplatnost hlasování a neplatnost voleb a v této souvislosti také definici volební kampaně a jejímu následnému přezkumu. Postupujeme přitom od nejvíce úspěšného typu návrhu v podobě neplatnosti volby kandidáta po ten nejméně úspěšný (neplatnost voleb jako celku). Současně jde také o postup zohledňující „závažnost“ pochybení, nebot' $\mathrm{v}$ prrípadě neplatnosti volby kandidáta dojde pouze ke změně v osobách zvolených kandidátů, zatímco v prrípadě neplatnosti voleb je nutné opakovat celý volební proces a všechny jeho fáze, tedy od nejméně závažného pochybení.

1 Mnohá z našich níže popsaných zjištění a závěrů jsou současně mutatis mutandis platná také pro soudní přezkum aktuálně proběhlých voleb do krajských zastupitelstev, resp. soudní přezkum voleb obecně, a nevztahují se tak čistě na komunální volby v roce 2018, na něž jsme se v našem podrobném výzkumu zaměrili.

2 Od soudů jsme si vyžádali seznamy všech rozhodnutí ve věci komunálních voleb 2018 a samotná rozhodnutí jsme si následně opatřili z webu Nejvyššího správního soudu, popřípadě jsme si je dodatečně vyžádali, pokud nebyla zveřejněna na internetu. Pro úplnost upozorňujeme na náš článek publikovaný v č. 1/2020 tohoto časopisu, který je sice věnován odlišným (zejména procesním) otázkám, nicméně vychází ze stejné analýzy. Proto lze odkázat minimálně na jeho část věnovanou metodologii. FERFECKÝ, Jan, SCHEUER, Jan a Josef ŠÍP. Volby do obecních zastupitelstev 2018 - analýza volební judikatury krajských soudů. Casopis pro právní védu a praxi, 2020, č. 1, s. 71-94. Dostupné z: https://journals.muni.cz/cpvp/article/view/12592

3 V tomto příspěvku je naprostá většina prostoru věnována pouze praktickým otázkám plynoucím z provedené analýzy. Obšírněji je téma soudního přezkumu voleb zpracováno např. v publikaci MOLEK, Pavel a Vojtěch ŠIMÍČEK .Soudni prezkeum voleb. Praha: Linde, 2006, ve vztahu k tomuto příspěvku zejména s. 283-309. 


\section{Základní výsledky výzkumu}

Pokud bychom měli prezentovat základní výsledky, k nimž jsme naší analýzou došli, pak z celkového počtu 228 usnesení $^{4}$ volební soudy ve 36 př́padech návrhy odmítly, aniž by se jimi vůbec věcně zabývaly; ve 3 případech pak bylo řízení zastaveno. Ve zbytku se soudy návrhy zabývaly meritorně - ve 176 př́ipadech návrhy zamítly a ve 13 věcech navrhovatelům vyhověly zcela, případně z části a rozhodly o neplatnosti voleb, hlasování, resp. volby kandidáty. Úspěšnost návrhů tak dosáhla přibližně 5,5 \% - nejčastěji bylo vyhověno návrhu na vyslovení neplatnosti volby kandidáta (v 10 případech ${ }^{5}$ ), další v pořadí byla neplatnost hlasování (ve 2 př́padech ${ }^{6}$ ) a na posledním místě se nacházelo rozhodnutí o neplatnosti voleb (v 1 př́padě7).

Úspěšnost návrhů může být posuzována také z hlediska toho, který krajský soud vyhověl návrhům nejčastěji. Zde je možné uvést, že nejvíce návrhů bylo podáno ke Krajskému soudu v Ostravě (vč. jeho olomoucké pobočky), a to celkem 44; návrhu však tento soud vyhověl pouze v jediném př́padě. Krajský soud v Ústí nad Labem ani Krajský soud v Plzni pak nevyhověly ani jednomu návrhu. Naopak nejprrívětivějším soudem dá-li se to takto nazvat - byl Krajský soud v Českých Budějovicích, jenž vyhověl třem ze 16 návrhů (tj. 18,75\%).

\begin{tabular}{|c|c|c|c|c|c|c|c|c|c|c|c|c|}
\hline Ukazatel & $\begin{array}{l}\tilde{U} \\
\stackrel{y}{\bar{J}} \\
\dot{U}\end{array}$ & 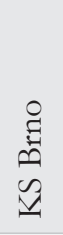 & 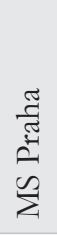 & 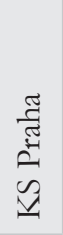 & $\begin{array}{l}\mathcal{D} \\
N \\
\bar{N} \\
\text { D }\end{array}$ & 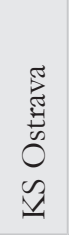 & 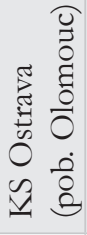 & 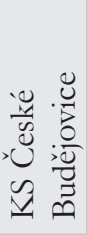 & 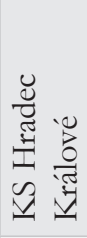 & 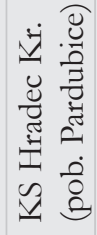 & 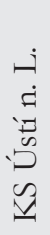 & 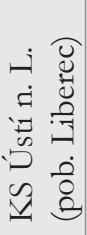 \\
\hline Celkový počet návrhů & 239 & 37 & 25 & 35 & 20 & 34 & 10 & 16 & 12 & 8 & 27 & 15 \\
\hline $\begin{array}{l}\text { Počet úspěšných návrhů } \\
\text { (alespoň částečně) }\end{array}$ & 13 & 2 & 3 & 3 & 0 & 1 & 0 & 3 & 1 & 0 & 0 & 0 \\
\hline $\begin{array}{l}\text { Procentní poměr } \\
\text { úspěšných návrhů (\%) }\end{array}$ & 5.5 & 5.4 & 12 & 12 & 0 & 2,94 & 0 & 18,75 & 8.3 & 0 & 0 & 0 \\
\hline
\end{tabular}

Zdroj: vlastní analýza autorů

4 Rozdílný počet usnesení oproti celkovému počtu podaných návrhů je dán jednak spojováním věcí (k čemuž došlo v pěti př́padech, přičemž spojení nastalo u Krajského soudu v Brně, Praze a Ostravě) a jednak skutečností, že v šesti př́padech byly návrhy vyř́zeny pouhým přípisem (Krajský soud v Brně takto vyřešil 2 př́pady, Krajský soud v Ostravě 3 a jeho pobočka v Olomouci 1 př́pad). Pro úplnost uvádíme, že spojené věci byly v rámci naší analýzy vyhodnocovány stejně jako věc, se kterou byly spojeny.

5 Přehled úspěšných návrhů na neplatnost volby kandidáta je dostupný z: https://volby.cz/pls/kv2018/ kvs? xjazyk=CZ

6 Usnesení Krajského soudu v Praze ze dne 6. 11. 2018, č. j. 51 A 9/2018-176, a usnesení Krajského soudu v Českých Budějovicích ze dne 14. 11. 2018, č. j. 52 A 7/2018-87.

7 Usnesení Krajského soudu v Českých Budějovicích ze dne 17. 5. 2019, č. j. 52 A 16/2018-310, resp. usnesení Ústavního soudu ze dne 9. 8. 2019, sp. zn. IV. ÚS 1767/19, prrípad Strakonice. 


\section{Zákonná úprava a judikatorní východiska přezkumu voleb}

Soudní přezkum voleb je nezbytnou garancí férových voleb, které odpovídají vưli voličů, a legitimity na základě těchto voleb ustanovených orgánů veřejné moci. Zákon č. 150/2002 Sb., soudní řád správní, ve znění pozdějších předpisů (dále též jen „soudní rád správni“" nebo „S. ř. s.“) v části věnované soudní ochraně volebního procesu upravuje dva typy řízení, které voličům poskytují ochranu předběžnou (ochrana ve věcech seznamů voličů dle $\int 88$ s. ř. s.; a ochrana ve věcech registrace dle \ 89 s. r. s.). Dále tato část upravuje tři druhy návrhů, prostřednictvím kterých je poskytována ochrana následná (návrhy podle $\int 90$ s.řs.s., tedy na neplatnost voleb, hlasování nebo volby kandidáta). Předmětem našeho výzkumného záměru byla pouze ochrana následná.

K fázi preventivní nyní uvádíme pouze tolik, že i v rámci řízení o návrzích na vyslovení neplatnosti (voleb/hlasování/volby kandidáta) se lze v nezanedbatelné míre setkávat s argumentací, která směřuje do fáze předchozí - zejména brojí proti procesu registračnímu. Tyto námitky jsou s ohledem na zásadu souslednosti jednotlivých přezkoumávaných stádií, ve fázi povolební již v zásadě neprípustné. ${ }^{8}$ Tento názor byl ovšem v praxi relativizován a soudy občas i tyto námitky v pozdější fázi připouští a věcně se jimi zabývajii. ${ }^{9} \mathrm{~V}$ řízení o vyslovení neplatnosti komunálních voleb 2018 byly např́iklad připuštěny „registrační námitky na základě argumentace absencí procesní legitimace navrhovatelky k podání návrhu v předchozí fázi volebního procesu. Krajský soud v Praze v tomto př́ípadě uvedl, že ,nedostatek aktivity volebnich stran v rámci registračního procesu mữ̌e svými námitkami samotný volič nabrazovat pouze v nejkeriklavejš̌ch přphadech, kdy nelze pochybovat o tom, že neúplné č nepravdivé údaje uvedené u jednotlivých kandidáti výsledek voleb skutečně brubè ovlivnily. " ${ }^{10} \mathrm{~V}$ jiné věci ${ }^{11}$ se soud tímto typem námitek věcně zabýval s odůvodněním, že se jedná o ,závažná tvrzení‘ “12.

Výše uvedený názor ohledně př́pustnosti námitek nelze považovat za univerzálně platný, dle našeho názoru lze spíše vycházet z toho, že ve většině případů tento typ námitek nebude úspěšný, a to ani v tom prípadě13, kdy př́slušný navrhovatel neměl možnost

8 Tento závěr byl vysloven v souvislosti se senátními volbami již v usnesení Nejvyššího správního soudu ze dne 9. 12. 2004, č. j. Vol 11/2004-31, č. 471/2005 Sb. NSS, kde bylo řečeno, že ,domáhat se vydání

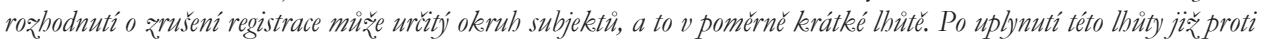
registraci brojit nelz̨e. "Nejvyšší správní soud se k otázce přesto v rovině obiter dictum vyjádřil.

9 I v odborné literatuře najdeme tento názor vztažený na případy, kdy by vady spočívající v předchozí fázi volebního procesu měly způsobit „zatemněni““ volebních výsledků. Jako př́klad jsou uváděny účelově hlášené trvalé pobyty (viz BLAŽEK, Tomáš a kol. Soudni rád správni - online komentár. Praha: C. H. Beck, 2016, komentář k $\left.\int 90\right)$.

10 Viz usnesení Krajského soudu v Praze ze dne 1. 11. 2018, č. j. 54 A 131/2018-46.

11 Viz usnesení Krajského soudu v Ostravě ze dne 7. 11. 2018, č. j. 21 A 8/2018-39.

12 Navrhovatel zpochybňoval svou kandidaturu a svůj podpis na př́slušných listinách označil za falešný.

13 Výslovně např́klad v usnesení Krajského soudu v Ostravě ze dne 22. 10. 2018, č. j. 24 A 9/2018-19, kde soud uvedl, že otázky týkající se registrace kandidátních listin již nemůže řešit, přičemž poukázal i na to, že navrhovatel nebyl ani aktivně legitimován k podání takového návrhu. 
podat návrh na ochranu v předchozí fázi volebního procesu ${ }^{14}$. V zásadě by mělo platit, že navrhovatel brojící pouze proti otázkám souvisejícím s registrací by neměl být způsobilý svým návrhem vyvolat řízení o následném přezkumu voleb. Jestliže brojí proti volbám, hlasování či volbě kandidáta a společně s tím uvádí i námitky související s registrací, neměly by takové námitky dle našeho názoru být pro přezkum soudu relevantní.

Pokud se vrátíme k následné ochraně voleb, úprava obsažená v \90 a násl. s. ř. s. se vztahuje na všechny typy voleb - bližší podmínky pro podání návrhu soudní řád správní svěřuje zvláštním zákonům. $V$ případě soudního přezkumu komunálních voleb je oním zvláštním zákonem zákon č. 491/2001 Sb., o volbách do zastupitelstev obcí a o změně některých zákonů (dále jen ,zákon o volbách do obecních zastupitelstev“). Ten v \60 odst. 1 věta prvá stanoví, že podáním návrhu na neplatnost hlasování, na neplatnost voleb nebo na neplatnost volby kandidáta se může domáhat ochrany u soudu každá osoba zapsaná do seznamu ve volebním okrsku, kde byl člen zastupitelstva obce volen, stejně jako každá volební strana, jejíž kandidátní listina byla zaregistrována pro volby do tohoto zastupitelstva. Zákon však nevymezuje vztah mezi jednotlivými návrhy, rovněž se nedozvíme, jaké jsou př́ípadné odlišnosti jednotlivých řízení. V zásadě jediné specifikum, které můžeme vyčíst, se týká řízení o návrhu na neplatnost volby kandidáta, resp. rozhodnutí soudu v tomto řízení, jelikož \90 odst. 4 s. r. s. umožňuje soudu, aby současně s rozhodnutím o neplatnosti volby kandidáta vyhlásil za zvoleného toho, kdo byl řádně zvolen. Na tomto místě lze odkázat na závěry Ústavního soudu, ${ }^{15}$ který k jednotlivým návrhům uvedl, že př̀i zjištění porušení volebního zákona by měl soud při zjišt'ování skutkového stavu a právním posouzení věci vždy postupovat od posouzení varianty prohlášení neplatnosti voleb jako celku k ostatním ve volebním zákoně uvedeným „dílčím“ variantám.

Přes uvedenou „úspornost“ zákonné úpravy však lze vypíchnout klíčové východisko, kterým se řídí soudní přezkum voleb bez ohledu na prríslušný druh návrhu, a tím je tzv. presumpce správnosti zjištěného volebního výsledku, tj. výsledek voleb, jak byl vyhlášen volební komisí, je presumován jako správný, a platí vyvratitelná domněnka, že volební výsledek odpovídá vưli voličù. ${ }^{16}$ Zásahy do takto zjištěného výsledku mají nastat pouze za určitých kvalifikovaně zjištěných skutečností, které vyvolávají pochybnosti o správnosti zjištěného výsledku daných voleb. Možná trochu zvláštně je základním východiskem soudního přezkumu důraz na co nejmenší zásahy soudní moci do výsledků voleb (tedy již a priori vyjadřované sebeomezení soudní moci); tuto premisu jsme také v rámci naší analýzy hojně zaznamenávali. Soud tak sice může přistoupit k přepočtu hlasů či přezkumu správnosti jejich posouzení, činí tak ovšem jen výjimečně, pouze na základě

14 Srov. MIKEŠ, Petr. In: KÜHN, Zdeněk a kol. Soudni rád správni: komentár. Praha: Wolters Kluwer, 2019, s. 764.

15 Nález Ústavního soudu ze dne 18. 1. 2011, sp. zn. Pl. ÚS 57/10.

16 Srov. nález Ústavního soudu ze dne 26. 1. 2005, sp. zn. Pl. ÚS 73/04. 
tzv. „zvláště významné indicie“, která by byla způsobilá vyvolat pochybnosti o správnosti vyhlášeného výsledku voleb.

Současně by mělo být pamatováno na algoritmus přezkumu voleb vyjádřený Nejvyšším správním soudem ${ }^{17}$, $\mathrm{k}$ němuž se přihlásil i Ústavní soud, když uvedl: „Ve smyslu jeho závěru je třeba hodnotit (1.) nezákonnost, trn. porušeni nèkterých ustanovení volebnich zákonü, (2.) existenci vžtahu (souvislosti) mezi touto nezákonností a volebnim výsledkem a (3.) zásadni intenzitu této nezákonnosti, která ve svých dìsledcich musi prinejmenšim výrazně volebni výsledek apochybňovat, tj. odìvodňovat závèr, že by volby dopadly odlišnè, pokud by nedošlo ke zjišténé nezákonnosti. "18

Zejména s 3. krokem tohoto algoritmu souvisí legislativní změna zákona o volbách do zastupitelstev obcí19 (na jejíž aplikaci v praxi volebních soudů jsme se také zaměřili), podle které byl výraz „zpiisobem, který mohl ovlivnit výsledky voleb“ změněn na „zpiisobem, který hrubě ovlivnil výsledky". Ústavní soud k dané legislativní změně uvedl, ${ }^{20}$ že „,[n]ově formulovaný požadavek na brubé ovlivnèni výsledku je v zásadě jen jiným vyjádrením požadavku nálezu sp. zn. Pl. ÚS 73/04 na zásah volebního soudu ve výjimečných prīpadech (...). "Za hrubé ovlivnění volebního výsledku Ústavní soud považuje ,jiné rozděleni mandátư, nežjaké odpovídá viili voličů. "Současně ale Ústavní soud upozornil na věcnou změnu, která nastala $\mathrm{v}$ důsledku této novelizace, nebot' pro zásah soudu již nepostačí ,pravdępodobnost ovlivnèní, ale je treba prokázat samotné ovlivnèní. "21 K tomu Ústavní soud dále doplnil, že „,p]ro závèr o brubém ovlivnèni voleb je tedy uríujici komplexni hodnoceni skutkovébo stavu zjištèného v (časovè) omezených možnostech volebního soudu z. blediska toho, zda skutková tvrzení o jiném prídèleni mandátů, pokud by nebylo došlo k. vadě volebního procesu, odpovidaji žkušenostem běžnébo života a soudce je o jejich pravdivosti vnitřněpresvédčen bez rozumných pochybností. "Lze proto uzavřít, že stávající úprava klade na navrhovatele přísnější požadavky než ta předchozí.

\section{Několik poznámek $\mathrm{k}$ dokazování ve volebním soudnictví}

V souvislosti s výše uvedeným považujeme za potřebné zevrubněji předestřít také problematiku a limity dokazování ve volebním soudnictví a s tím související zjištění našeho výzkumu. Předpoklad, že volební výsledek odpovídá vůli voličů, má totiž zásadní dopad na rozsah nároků kladených na navrhovatele, jakož i vyžadovanou intenzitu pochybností či prrímo volebních vad. Je to totiž ten, kdo volební vadu namítá (navrhovatel), kdo musí prokázat, že k pochybení došlo a že takové pochybení rovněž mělo náležitou

17 Viz usnesení ze dne 2. 7. 2004, č. j. Vol 6/2004-12, č. 354/2004 Sb. NSS.

18 Nález Ústavního soudu ze dne 2. 4. 2019, sp. zn. I. ÚS 4178/18.

19 Zákonem č. 322/2016 Sb., kterým se mění volební zákony a další související zákony.

20 Již odkazovaný nález Ústavního soudu ze dne 2. 4. 2019, sp. zn. I. ÚS 4178/18.

21 Za předchozí právní úpravy bylo možno požadavek na intenzitu protizákonnosti formulovat takto: „Tato

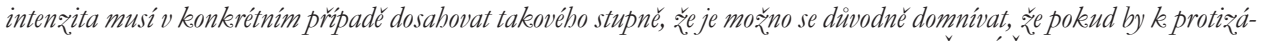
konnému jednáni nedošlo, dopadly by zrèmé volby odlišně. "MOLEK, Pavel a Vojtěch ŠIMÍČEK. Soudnípreqkeum voleb. Praha: Linde, 2006, s. 297. 
intenzitu; neboli že hrubě ovlivnilo výsledek voleb. Tento základní rámec soudního přezkumu vychází z toho, že funkce soudu nemůže být vykládána tak široce, že by v konečném důsledku měla nahrazovat či doplňovat činnost volebních orgánů na základě pouhé neprokázané či spekulativní námitky. ${ }^{22}$

Procesní terminologií řečeno tak navrhovatele tíží povinnost tvrzení a povinnost důkazní a s tím spojená procesní břemena; v této souvislosti jsme ostatně i v rámci našeho výzkumu zaznamenali $\mathrm{v}$ několika rozhodnutích argument, že řízení podle \ 90 s. ř. s. je řízením o návrhu a platí tak pro něj ustanovení \ 101 odst. 1 písm. a) a b) zákona č. 99/1963 Sb., občanský soudní rád (dále jen „o. s. ř.“), ve spojení s \ 64 s. ř. s., pročež je tedy na navrhovateli, aby zcela konkrétním způsobem tvrdil jak ,porušení volebního zákona“, tak skutečnosti, z nichž lze dovodit, že se tak stalo ,způsobem, který hrubě ovlivnil výsledky voleb“, a svá tvrzení také náležitě prokázal. V souladu s \120 odst. 1 a 2 o. s. ̌r. ve spojení s \64 s. ř. s. soud rozhoduje, které z navrhovaných důkazů provede; jiné důkazy může provést jen v př́padech, kdy jsou potřebné ke zjištění skutkového stavu a vyplývají-li z obsahu spisu. ${ }^{23}$ Navrhovatel tedy musí předložit relevantní a podložené námitky (nap̌r. o nečestné volební kampani, nesprávném průběhu hlasování, zjevných logických chybách v sečtení hlasů) a navrhnout patřičné důkazy (výslechy svědků, fotografie, videozáznam, přepočet hlasů apod.), což klade na navrhovatele značné nároky. Důkazní návrhy kladou - hlavně s ohledem na požadavek rychlosti rozhodování - značné požadavky i na soud, nutno totiž zdůraznit, že nezbytnou součástí dokazování je požadavek ústního jednání, které jinak ve volebním soudnictví obligatorní není. ${ }^{24}$ Dodejme ještě, že navrhovatel musí všechny skutkové a právní důvody, o které opírá svůj návrh, uplatnit ve lhưtě pro jeho podání (dochází ke koncentraci řízenî), nicméně relevantni důkazní návrhy může dle výkladu Ústavního soudu ${ }^{25}$ uplatnit i později, přičemž mohou být odmítnuty jako opožděné pouze v př́padě, pokud by jejich provedení znemožnilo soudu dodržet lhůtu k rozhodnutí.

V tomto směru jsme identifikovali - bylo-li to z odůvodnění rozpoznatelné - že důkazy byly navrhovány pouze v 64 návrzích, tj. v cca $25 \%$ př́padů, v ostatních věcech navrhovatelé důkazy sami vưbec nezmiňovali. Pokud jde o povahu důkazního návrhu, nejčastěji se jednalo o návrh na opakované přepočtení hlasů v okrsku, př́ípadně celé obci (lze-li tedy přepočet za dokazování označit - viz podkapitola 4.2). Ze všech případů, ve kterých navrhovatelé navrhovali i provádění důkazů, bylo pouze ve 14 př́padech

22 Viz např. usnesení Nejvyššího správního soudu ze dne 28. 11. 2006, č. j. Vol 82/2006-51.

23 Např. usnesení Krajského soudu v Plzni ze dne 7. 11. 2018, č. j. 57 A 132/2018-105.

24 Srov. $\int 90$ odst. 3 s. ř. s.

25 Nálezem Ústavního soudu ze dne 27. 3. 2019, sp. zn. III. ÚS 35/19, bylo zrušeno usnesení Krajského soudu v Ústí nad Labem ze dne 7. 11. 2018, č. j. 40 A 27/2018-159, kterým byly důkazní návrhy uplatněné po lhůtě pro podání návrhu (přičemž je navrhovatel mohl uplatnit dříve) odmítnuty jako opožděné, přestože soud nařídil jednání, na kterém provedl včas uplatněné důkazní návrhy. 
(tedy pouze v cca $22 \%$ prrípadů) nařízeno ústní jednání. ${ }^{26}$ Bez návrhu k dokazování ze strany navrhovatelů bylo soudy k ústnímu jednání přistoupeno pouze ve 2 př́padech. Pro zajímavost také dodáváme, že u 5 prrípadů, kdy došlo k nařízení ústního jednání, nebyla soudem dodržena lhůta pro vydání rozhodnutí (přičemž celkově tato lhůta nebyla dodržena v 9 prŕpadech ${ }^{27}$ ). Zdůrazněme však, že lhưta pro vydání rozhodnutí má pouze pořádkový charakter. Jejím účelem je indikovat prioritu volebních věcí a nemá pro soud představovat překážku při důsledném vyhodnocení všech rozhodných skutečností. ${ }^{28}$ Vzhledem k jednoznačnému důrazu na rychlost rozhodování ve volebních věcech by dle nás k jejímu překročení mělo docházet pouze minimálně a vždy z objektivních důvodů, pro které nebylo možné dosáhnout účelu soudního přezkumu ve stanovené lhůtě.

Za poněkud problematické považujeme př́pady, kdy soud konstatoval nutnost doplnit skutkový stav nad rámec zjištění z volební dokumentace a za tímto účelem si vyžádal vyjádření k návrhu od členů okrskové volební komise a další listinné podklady (spis Policie České republiky, záznam o výjezdu hlídky městské policie), ${ }^{29}$ ač by dle našeho názoru bylo namístě nařídit ústní jednání a provést př́slušné dokazování. ${ }^{30}$ Některé soudy postupovaly obdobně, ovšem méně problematicky. Svůj postup totiž vysvětlily tím, že o návrhu bylo možné rozhodnout na základě navrhovatelem předložených listin a předložené volební dokumentace (což nebyl předchozí případ - v těchto případech $\mathrm{k}$ př́slušnému návrhu byla navíc předložena např́klad čestná prohlášení ${ }^{31}$ nebo fotografie vylepeného letáku ${ }^{32}$ ). Ač v odůvodnění těchto rozhodnutí není výslovně zmíněno, jejich postup by mohl být inspirován jeho subsidiárním užitím. Toto ustanovení totiž civilním soudům umožňuje rozhodnout bez jednání, pokud je to možné na základě účastníky předložených listin a pokud s rozhodnutím bez jednání účastníci souhlasí (nebo se práva účasti na jednání vzdali).

26 Soud samozřejmě není povinen dưkaznímu návrhu vyhovět, jelikož rozsah dokazování závisí na jeho úvaze. To dobře demonstruje i situace, kdy při posuzování v zásadě totožné otázky (vliv hlasování do nesprávných obálek způsobeného souběhem komunálních a senátních voleb v daném obvodu) jeden soud prováděl rozsáhlé dokazování (usnesení Nejvyššího správního soudu ze dne 6. 11. 2018, č. j. Vol 76/2018-105) a druhý soud se naopak spokojil s volební dokumentací, která odpovídala nesporným tvrzením účastníků řízení (usnesení Krajského soudu v Brně ze dne 7. 11. 2018, č. j. 64 A 14/2018-28).

27 Nicméně musíme dodat, že v řadě dalších případů se tento parametr na základě skutečností uvedených v odůvodnění nedal zjistit.

28 Takto svůj postup odůvodnil např. Krajský soud v Českých Budějovicích v prrípadě voleb do zastupitelstva Strakonic (usnesení ze dne 20. 11. 2018, č. j. 52 A 16/2018-195, bod 93) a my se s tímto zdůvodněním zcela ztotožňujeme.

29 Usnesení Krajského soudu v Praze ze dne 7. 11. 2018, č. j. 43 A 141/2018-82, bod 40 a násl.

30 Význam ústního jednání spočívá zejména $\mathrm{v}$ tom, že výhradně při jednání může soud provádět dokazování, na jehož základě činí prríslušná skutková zjištění. Viz rozsudek Nejvyššího správního soudu ze dne 14. 7. 2005, č. j. 3 Azs 103/2005-76.

31 Usnesení Krajského soudu v Ústí nad Labem - pobočka v Liberci ze dne 6. 11.2018, č. j. 64 A 21/2018-113, bod 15 ve spojení s bodem 20.

32 Usnesení Krajského soudu v Ústí nad Labem ze dne 2. 11. 2018, č. j. 64 A 19/2018-45, bod 11 ve spojení s bodem 19 . 


\section{Zvlášt' významná indicie jako nezbytný předpoklad pro následný přezkum (přepočet) zjištěných volebních výsledků}

Nyní již ovšem přecházíme k představení našich zjištění ve vztahu k př́ípadům a důvodům, kdy soudy přistupují k podrobnému zjišt’ování volebních vad. Přiblížíme význam tzv. zvlášt' významné indicie a zaměříme se zejména na př́pady přepočtu hlasů: kdy a za jaké situace se k němu soudy uchylují (je-li dána korelace mezi prrítomností zvlášt' významné indicie a přepočtem hlasů), zda lze identifikovat rozdíly v jejich př́stupu a v jaké podobě přepočet provádějí.

\subsection{Povaha a význam důvodných pochybností soudu (zvlášt' významná indicie)}

Výše předestřené premisy soudního přezkumu voleb by totiž samy o sobě byly poměrně prŕísné. Požadavky kladené na navrhovatele (povinnost předložení relevantních důkazů) se mohou jevit jako prakticky obtížně realizovatelné, ve svém důsledku bránící rádnému soudnímu přezkumu voleb a tvořící překážku přístupu $\mathrm{k}$ soudu; to zvláště v prrípadě občanů, kteří nebyli účastni sčítání hlasů a nemají tak prostředky, jak volební pochybení prokázat. Judikatura proto dovodila, že soud může v př́padě pochybností o správnosti volebních výsledků $\mathrm{k}$ provedení důkazů, resp. přepočtu hlasů přistoupit i sám. ${ }^{33}$ $\mathrm{K}$ tomuto kroku přistoupí tehdy, jestliže se ve věci vyskytne tzv. „zvlást' významná indicie", která je způsobilá vyvolat pochybnosti o správnosti vyhlášeného výsledku voleb. Právě existence významné indicie - důvodné pochybnosti - je středobodem věcného přezkumu voleb, nebot' právě na identifikaci takové skutečnosti závisí, zda se soud bude návrhem podrobně věcně zabývat a provede přepočet hlasů.

Zde je nutné zdůraznit, že samotný pojem ,zulást' významná indicie“ se v judikatuře primárně váže ke kontrole správného sečtení hlasů a úzce tak souvisí s přepočítáváním hlasů soudem. Jinak řečeno, o závažné indicii zpravidla hovoříme v souvislosti s návrhem na neplatnost volby kandidáta(ů), při němž soud pouze koriguje vyhlášené volební výsledky tak, aby odpovídaly jím zjišsěné vưli voličů, a tím volební proces také ukončí; níže uvedené závěry se tedy týkají především návrhů na neplatnost volby kandidáta/ů. Pro úplnost je však nutné dodat, že i v př́ipadě návrhu na neplatnost voleb či hlasování, kdy není napadáno početní pochybení při sčítání hlasů nebo přepočtu na mandáty [ale takové vady, u nichž nelze vưli voličů zjistit (a výsledky tak ,pouze“ dopočítat a korigovat)], nepochybně musí existovat důvodná pochybnost (byt' zřejmě nehovoříme přímo o zulást významné indicii) o řádném průběhu volebního procesu, která soud vede $\mathrm{k}$ tomu, aby se tvrzeními navrhovatele podrobně zabýval a v tomto směru též vedl dokazováníi v těchto případech tak musí být tvrzení navrhovatele náležitě relevantní. Pochybnosti $\mathrm{v}$ tomto směru může vyvolávat např. porušení zabezpečení volební urny ${ }^{34}$, jednostranné

33 Srov. zejména shora citované usnesení Nejvyššího správního soudu č. j. Vol 82/2006-51.

34 Usnesení Krajského soudu v Českých Budějovicích ze dne 2. 11. 2018, č. j. 52 A 12/2018-60. 
upřednostňování volební kampaně jen určité volební strany městem ${ }^{35}$, nápadné přihlášení osob $\mathrm{k}$ trvalému pobytu $\mathrm{v}$ obci $\mathrm{v}$ době těsně předcházející volbám ${ }^{36}$ či podezření ${ }^{37}$ na kupčení s hlasy. ${ }^{38}$

V obecné rovině lze na základě provedeného výzkumu uvést, že relevantnost stížních tvrzení byla (u všech druhů návrhů) značně kolísavá. Ve velké míře se objevovaly námitky zcela obecného charakteru v podobě prostého nesouhlasu s výsledky voleb (např. že kandidát nezískal v daném okrsku žádný hlas, což je statisticky nepravděpodobné) či kritiky zvolených zastupitelů (nebot' obec špatně spravují či se obohacuji z obecního rozpočtu). Mnohdy šlo o argumenty až úsměvné: tvrzeným vadám tak měl např. v jednom př́padě nasvědčovat „i velmi prekevapivý výrazjedné z členek volebni komise "39; v jiném případě navrhovatel provedl vlastní šetření, které uskutečnil před konkrétními volebními místnostmi v noci ze dne 5. října na 6. ř́jina 2018, když soudu ve svém návrhu dobrodružnou formou zprostředkoval, jak sledoval pohyb neznámé osoby kolem volební místnosti a viděl také rozsvícené světlo. ${ }^{40}$ Oproti tomu relevantních volebních stížností, jež nebylo možné a priori označit za nedůvodné až bezpředmětné, byla výrazná menšina. Tuto skutečnost lze ostatně ilustrovat na dvou statistických ukazatelích - počtu ústních jednání, jichž bylo nařízeno 16, a př́ipadech přepočítání hlasů, jichž jsme napočítali celkem 27.

Za zvlášt' významné indicie tak nelze - dle soudů - považovat spekulativní souvislosti např. $\mathrm{v}$ podobě značně rozdílného počtu neplatných hlasů v jednotlivých okrscích; zvláště, pokud zde je racionální vysvětlení [liberecká pobočka Krajského soudu v Ústî nad Labem tak zmínila skutečnost, že v některých okrscích města Liberce se volilo zároveň do zastupitelstva městské části a zároveň do „velkého“ zastupitelstva (tzn. složitěji), čímž lze zdůvodnit také větší počet neplatných hlasů]. ${ }^{41}$ Obdobně, jak jsme uvedli výše, ani Krajský soud v Brně nepovažoval nápadné rozdíly v počtech neplatných hlasů mezi okrsky za dostatečně významnou indicii a pokud prováděl přepočet, bylo to z jiného důvodu. Zajímavé ovšem je, že při přepočtu bylo zjištěno, že výrazný počet neplatných hlasů byl chybný a velká část z nich měla být posouzena jako hlasy platné. ${ }^{42} \mathrm{~V}$ této souvislosti tak lze považovat za značně pochybný základní předpoklad soudního přezkumu, tj. presumpce správnosti volebního výsledku.

35 Srov. usnesení Krajského soudu v Českých Budějovicích ze dne 17. 5. 2019, č. j. 52 A 16/2018-310.

36 Srov. usnesení Krajského soudu v Brně ze dne 8. 11. 2018, č. j. 64 A 16/2018-205.

37 Srov. usnesení Krajského soudu v Ústí nad Labem ze dne 6. 11. 2018, č. j. 40 A 32/2018-60.

38 Zajímavou otázkou by mohl být i př́ípad, kdy navrhovatelka tvrdila, že na sídlišti nalezla množství zaškrtnutých volebních lístků s tím, „že doma nalezené lístky suší a až uschnou, tak je soudu doloži“،, jestliže by návrh nebyl odmítnut a navrhovatelka skutečně usušené lístky předložila. Viz usnesení Krajského soudu v Českých Budějovicích ze dne 29. 10. 2018, č. j., 52 A 14/2018-9.

39 Usnesení Krajského soudu v Brně ze dne 6. 11. 2018, č. j. 64 A 15/2018-37.

40 Usnesení Krajského soudu v Českých Budějovicích ze dne 2. 11. 2018, č. j. 52 A 12/2018-60.

41 Usnesení Krajského soudu v Ústí nad Labem, pobočky Liberec ze dne 5. 11. 2018, č. j. 64 A 18/2018-31.

42 Usnesení Krajského soudu v Brně č. j. 63 A 8/2018-35. 
V návrzích na neplatnost volby kandidáta/ů je velmi často argumentováno nejen rozdílnými počty neplatných hlasů v jednotlivých okrscích, ale též existencí množství neplatných hlasů vůbec. Tady (oproti př́padům nápadných rozdílů mezi okrsky, které dle okolností věci mohou podle nás vypovídat o možném pochybení při sčítání hlasů) vidíme základní problém už v samotném předpokladu navrhovatelů, že vysoký počet neplatných hlasů je a priori podezřelý. V takových prrípadech totiž může jít (a také jde) jen o nevyužité hlasy voličů, ne hlasy nutně neplatné. To souvisí se způsobem hlasování v obecních volbách, kdy mají voliči k dispozici určitý počet hlasů, které mohou, ale také nemusí využít. ${ }^{43}$ Volební evidence ovšem tyto souvislosti nezohledňuje - v zápise o průběhu a výsledku hlasování se zaznamenává počet voličů a počet platných hlasů odevzdaných pro každou volební stranu a jednotlivé kandidáty, nikoli však hlasy neplatné. ${ }^{44}$ To vede $\mathrm{k}$ tomu, že všechny zbývající hlasy (tj. rozdíl mezi platnými hlasy a celkovým počtem hlasů, které měli voliči $\mathrm{k}$ dispozici) jsou považovány za hlasy neplatné. Jinak řečeno, neplatné a nevyužité hlasy spadají do ,jednoho pytle“. V této souvislosti jsme $\mathrm{v}$ rámci naší analýzy zaznamenali i podnětný návrh de lege ferenda, reagující na tento problém tak, že by v zápise okrskové volební komise měly být zaznamenány i (skutečně) neplatné hlasovací lístky, tak jak tomu je u dalších volebních zákonů. ${ }^{45}$ Tato snadno realizovatelná změna by i podle nás mohla $\mathrm{v}$ mnoha případech snížit podežrení navrhovatelů o možných nepravostech a tím také odlehčit volebnímu soudnictví.

Zaměříme-li se ale čistě na identifikování zvlášt' významných indicií, zde jsme se dopočítali 18 př́padů, v nichž soudy dospěly k pochybnostem o správnosti volebních výsledků, a proto také provedly přepočet hlasů; zajímavostí je, že osm případů bylo rozhodováno Krajským soudem v Brně a všechny ostatní krajské soudy dohromady shledaly zvlášt' významnou indicii jen v 10 př́padech. Identifikace kvalifikované indicie a navazující přepočet hlasů pak vedla $\mathrm{k}$ vyhovění návrhu jen v osmi prŕípadech (tedy přibližně polovině), v ostatních byl návrh přes provedenou kontrolu zamítnut jako nedůvodný.

Skutečnosti, jež zakládaly důvodné pochybnosti, byly různé povahy a intenzity a pohybovaly se od zcela nekonkrétních podezření, - tak soud přistoupil k přepočtu hlasů ve třech okrscích s ohledem na celkový kontext obsahu návrhu (obecně byly namítány nesrovnatelnosti ve třech okrscích spočívající v nepoměrech hlasů mezi kandidáty či v rozdílu mezi vydanými a spočtenými obálkami) ve spojení se skutečností, že př́íslušná strana získala skoro $5 \%$ hlasư ${ }^{46}$, nebo v situaci, kdy navrhující strana získala ve volbách 7,02\%

\footnotetext{
43 Srov. \34 zákona o volbách do obecních zastupitelstev, který popisuje možnost tzv. panašování, tedy volby kandidátů naprŕíc listinami, resp. volby kandidátů vedle volební strany (voliči mají k dispozici tolik hlasů, kolik se volí členů zastupitelstva).

44 Srov. $\int 42$ odst. 2 zákona o volbách do obecních zastupitelstev.

45 Usnesení Krajského soudu v Brně ze dne 7. 11. 2018, č. j. 63 A 8/2018-35.

46 Usnesení Krajského soudu v Brně ze dne 6. 11. 2018, č. j. 64 A 11/2018-65.
} 
hlasů a přesto nezískala $v$ zastupitelstvu obce žádný mandát ${ }^{47},-$ až po pochybnosti zcela konkrétní, jež považujeme za praktické přehledně vyjmenovat:

- vložení hlasovacích lístků do nesprávných (opačných) obálek v souvislosti se souběžným konáním senátních voleb (šeda x žlutá), které však materiálně vyjadřovaly vůli voličư ${ }^{48}-\mathrm{v}$ extrémním př́padě by tato vada mohla vést až $\mathrm{k}$ vyslovení neplatnosti celého hlasování,

- někteří kandidáti obdrželi nápadně nepravděpodobný, resp. minimální počet hlasů (bud' 1, nebo žádný), přestože pro celou stranu hlasovalo několik voličư, ${ }^{49}$

- někteří kandidáti neměli ani hlas, ačkoli jejich volební strana hlasy dostala, to navíc ve spojení s vysokým počtem neplatných hlasů, jenž však samostatně soud za významnou indicii nepovažoval (viz níže), ${ }^{50}$

- výrazné rozdíly v jednotlivých okrscích, ${ }^{51}$

- markantní rozdíl v získaných hlasech v jednom okrsku oproti jiným, ${ }^{52}$

- započítání hlasů pro mrtvého kandidáta, ${ }^{53}$

- kandidátka získala podezřele moc hlasů (dle navrhovatelů bylo vydáno 209 obálek, přičemž jediná kandidátka měla získat nepravděpodobných 200 hlasů, což navíc vůbec neodpovídalo diskusím s ostatními voliči $),{ }^{54}$

- navrhovatelka namítala, že sama obdržela $100 \%$ hlasů, ${ }^{55}$

- situace, kdy všichni navrhovatelé potvrdili písemným čestným prohlášením hlasování tzv. velkým křížem pro celou volební stranu, jež ovšem neodpovídalo výslednému počtu hlasů, ${ }^{56}$

- tvrzení zapisovatelky okrskové volební komise, že komise nesprávně hodnotila hlasovací lístky jako neplatné, aby posléze tyto hlasovací lístky započítala jako platné

47 Usnesení Krajského soudu v Brně ze dne 7. 11. 2018, č. j. 64 A 13/2018-51.

48 Usnesení Krajského soudu v Brně ze dne 7. 11. 2018, č. j. 64 A 14/2018-28; obd. rozhodnutí téhož soudu sp. zn. 67 A 8/2018.

49 Usnesení Krajského soudu v Brně ze dne 5. 11. 2018, č. j. 63 A 4/2018-101 ve věci dvou spojených návrhů; podobně usnesení Krajského soudu v Hradci Králové, pobočky Pardubice, ze dne 8. 11. 2018, č. j. 52 A 124/2018-49 a č. j. 52 A 125/2018-37.

50 Usnesení Krajského soudu v Brně ze dne 7. 11. 2018, č. j. 63 A 8/2018-35.

$51 \mathrm{~V}$ předmětném volebním okrsku byl počet platných hlasů odevzdaných pro volební stranu ANO 2011 pouze 237 hlasů, tj. 1,87 \% z celkového počtu hlasů, přičemž v sousedních volebních okrscích, jejichž sídlo se nacházelo na stejné adrese, byly počty odevzdaných platných hlasů pro ANO 2011 mnohem vyšší (3 021, to je 16,74 \%, 2925, to je 22,09 \%, resp. 2 455, to je 16,99\%; viz usnesení Městského soudu v Praze ze dne 1. 11. 2018, č. j. 14 A 213/2018-27.

52 Usnesení Krajského soudu v Ostravě ze dne 29. 10. 2018, č. j. 21 A 7/2018-19.

53 Usnesení Krajského soudu v Ostravě ze dne 6. 11. 2018, č. j. 21 A 12/2018-28.

54 Usnesení Krajského soudu v Českých Budějovicích ze dne 24. 10. 2018, č. j. 52 A 4/2018-21.

55 Usnesení Krajského soudu v Hradci Králové ze dne 30. 10. 2018, č. j. 30 A 117/2018-19.

56 Usnesení Krajského soudu v Českých Budějovicích ze dne 14. 11. 2018, č. j. 52 A 7/2018-87. 
(navrhovatelka $\mathrm{k}$ tomu dále tvrdila, že na webu došlo k náhlé změně výsledků, což ale dle soudu samo o sobě důvodnou pochybnost nezakládá), ${ }^{57}$

- chybný způsob sčítání hlasů ve spojení s rozdílnými výsledky ve dvou okrscích v obci, jakož i podpisem zápisu okrskové volební komise nestandardně mimo volební místnost (podle soudu měly být pochybnosti člena komise uvedeny už v tomto zápisu, nicméně ve spojení s pochybnostmi o reálné chybě při sčítání mohly svědčit o závažné indicii). ${ }^{58}$

Tento výčet samozřejmě není vyčerpávající, jistě si lze totiž představit i řadu dalších okolností vyvolávajících pochybnosti o volebním výsledku - v souvislosti se zmíněnými př́klady lze ovšem zobecnit a konstatovat tři základní zdroje závažných pochybností o správnosti volebních výsledků, jež jsme v našem výzkumu identifikovali:

1. Podstatné a nápadné nesrovnalosti mezi výsledky stran (kandidátů) v jednotlivých okrscích. Samotné nesrovnalosti ovšem nutně nestačí, nebot' vedle případného pochybení zde musí být také dopad na výsledek voleb - př́íčinná souvislost mezi možnou volební vadou a složením zastupitelského sboru. I bez přepočtu hlasů lze totiž usoudit, že ani tvrzené pochybení v určitém okrsku či okrscích by nemohlo mít vliv na výsledky voleb (na změnu rozložení mandátů, jejich obsazení či vưbec na překročení hranice $5 \%$ ). ${ }^{59}$

2. Plausibilní tvrzení navrhovatele o tom, že on (a případně i další osoby) volil stranu či kandidáta, kteří dle výsledků nemají hlas žádný (nebo mají hlasů jen minimum), přestože by nějaký hlas mít nutně měli ${ }^{60}$; našli jsme i rozhodnutí, v nichž soudy takové tvrzení označují za základní předpoklad pro vyvolání pochybnosti o správnosti vyhlášeného výsledku voleb. ${ }^{61} \mathrm{I} v$ tomto př́padě ovšem podle judikatury musí být tvrzené „,chybějícíc hlasy relevantní i z pohledu výsledků voleb. ${ }^{62}$ To znamená, že připočtení údajně nezapočtených hlasů musí vést ke změně výsledků voleb - překročení $5 \%$ hranice, jiné rozdělení mandátů či jiné pořadí kandidátů. Tento požadavek považujeme za logický i pochopitelný z pohledu zajištění efektivity soudního přezkumu, nicméně současně je potřeba upozornit, že i tvrzení několika oprávněných voličů, jejichž hlasy by samy o sobě na výsledku voleb ničeho nezměnily, mohou napovídat o existenci systémového pochybení (nezapočtení daleko většího počtu hlasů). Vždy proto bude záležet na okolnostech každého případu a povaze tvrzení navrhovatelů.

57 Usnesení Krajského soudu v Českých Budějovicích ze dne 23. 10. 2018, č. j. 52 A 2/2018-15.

58 Usnesení Krajského soudu v Brně ze dne 31. 10. 2018, č. j. 67 A 5/2018-50.

59 Srov. usnesení Městského soudu v Praze ze dne 5. 11. 2018, č. j. 14 A 216/2018-33, kdy Česká strana sociálně demokratická získala 4,18 \% hlasů (58930 hlasů), přičemž pro překročení $5 \%$ hranice by strana potřebovala získat minimálně 70450 hlasů. Tvrzené pochybení v jednom z volebních okrsků (všichni členové strany měli získat shodný počet hlasů) však mohlo zvýšit volební zisk ČSSD jen o 240 hlasů, a tudíž nijak nemohlo ovlivnit složení zastupitelstva.

60 Viz také usnesení Nejvyššího správního soudu ze dne 22. 10. 2014, č. j. Vol 18/2014-46.

61 Opět viz usnesení Městského soudu v Praze č. j. 14 A 216/2018-33.

62 Usnesení Krajského soudu v Ústí nad Labem, pobočky Liberec, ze dne 2. 11. 2018, č. j. 64 A 20/2018-67. 


\section{Pochybnosti vyplývající ze zápisu okrskové volební komise nebo od jejích} členů. Nejvyšší správní soud k tomu ve své volební judikatuře již několikrát uvedl, a krajské soudy to také $\mathrm{v}$ námi zkoumaném období hojně připomínaly, že členové okrskové volební komise jsou potenciálním zdrojem „zvláště významné indicie“, na jejímž základě volební soud zpravidla přistoupí k otevření volební dokumentace a přepočítání hlasů. Pokud kandidující politický subjekt nevyužije svého oprávnění a nedeleguje člena okrskové volební komise, jde to k jeho tíži co do možnosti přesvědčivě tvrdit konkrétní pochybení v práci volební komise a konkrétní porušení volebního zákona. ${ }^{63}$ Př́padné námitky (pochybnosti) musí být primárně uvedeny v zápise okrskové volební komise, striktní přístup dokonce uvádí, že k pozdějším námitkám člena komise lze přihlížet jen za situace, pokud přesvědčivě vysvětlí, proč je nevznesl již v samotném zápise. ${ }^{64}$

\subsection{Přepočet hlasů - jeho předpoklady a podoby}

Přepočtem hlasů se rozumí kontrola výsledku voleb ze strany soudu. Jde vlastně o kontrolu dosavadního spočtení hlasů, př́padně o kontrolu jejich převedení (přepočtu) na mandáty v zastupitelstvu. Obecně lze říci, že hlasy může soud přepočítat sám (zpravidla za pomoci odborného justičního personálu, především v podobě asistentů soudců či vyšších soudních úředníků) ${ }^{65}$, či může požádat Český statistický úřad (zde půjde zejména o aplikaci volební formule, tj. o přepočet rozdělení mandátů mezi úspěšné volební strany). Pokud jde o povahu přepočtu, ten zřejmě nejde označit za dokazování (neprobíhá ostatně při jednání), ale spíše za kontrolu podkladů pro rozhodnutí soudu jakési doplnění spisového materiálu. Potom se tedy uplatní srovnatelný princip platný při práci se správním spisem při standardním soudním přezkumu, nebot' tím se také nedokazuje. ${ }^{66}$

Již výše jsme uvedli, že z celkem 228 rozhodnutých věcí soudy provedly přepočítání hlasů ve 27 př́padech. Mezi jednotlivými soudy jsme ovšem identifikovali značné rozdíly. Největší podíl přepočtů měl Krajský soud v Brně, a to celkem deset, což tvořilo více než čtvrtinu všech jím projednávaných věcí, naopak Krajské soudy v Plzni a v Ústí nad Labem neprovedly přepočet žádný.

63 Viz usnesení Krajského soudu v Ústí nad Labem, pobočky Liberec, ze dne 9. 11. 2018, č. j. 64 A 13/2018-186 a v něm citované usnesení Nejvyššího správního soudu ze dne 22. 10. 2014 č. j. Vol 18/2014-46.

64 Např. usnesení Krajského soudu v Praze ze dne 24. 10. 2018, č. j. 43 A 121/2018-23.

$65 \mathrm{~K}$ tomu lze pro ilustraci zmínit mimořádné nasazení veškerého personálu Nejvyššího správního soudu při přepočtu několika set okrsků ve Středočeském kraji v souvislosti s volbami do Poslanecké sněmovny - viz usnesení zmíněného soudu ze dne 19. 11. 2017, č. j. Vol 58/2017-187; Nejvyšší správní soud zde přednesl zajímavý návrh (apel) na zrrízení zvláštní přezkumné volební komise, která by rozsáhlé přepočty uskutečňovala.

66 Např. rozsudek Nejvyššího správního soudu ze dne 29. 1. 2009, č. j. 9 Afs 8/2008-117, č. 2383/2011 Sb. NSS. 
Pečlivý čtenář si mohl povšimnout, že celkový počet př́padů přepočtu neodpovídá počtu identifikovaných významných indicií (18). Tento rozdíl je dán skutečností, že soudy někdy provádějí kontrolní přepočet hlasů i přes absenci zvlášt’ významné indicie, takř́ikajíc nad rámec, aby podpořily své závěry o nedůvodnosti uplatněných námitek. ${ }^{67}$ Z tohoto hlediska jsme proto pristoupili též $\mathrm{k}$ analýze a identifikaci toho, kdy byl přepočet pro posouzení klíčový a kdy šlo jen o přepočet nad rámec vypořádání námitek navrhovatelů: $z$ odůvodnění rozhodnutí bylo možné s určitostí dovodit, že podstatným pro posouzení věci byl přepočet ve 12 případech, $\mathrm{v} 9$ věcech byl proveden jen nad rámec (tzv. kontrolní přepočet), aniž by jej okolnosti případu vyžadovaly. ${ }^{68}$

Praxi kontrolních přepočtů ovšem hodnotíme pro její arbitrárnost jako značně problematickou. Jestliže totiž dojde k přepočtu hlasů bez konkrétního podezření, není potom zřejmé, proč $\mathrm{v}$ jiném př́padě $\mathrm{k}$ přepočtu hlasů nedošlo - vznikají tak neodůvodněné rozdíly. Zajímavý př́klad jsme identifikovali u Krajského soudu v Brně, kdy tentýž senát krajského soudu u malé obce (792 voličů) zcela nad rámec vypořádání návrhu prristoupil $\mathrm{k}$ přepočtu hlasů (dokonce úplnému) s odůvodněním, že chce vyloučit veškeré spekulace, ${ }^{69}$ nicméně u jiného obdobného případu, v němž však šlo o volby do zastupitelstva města Brna, to neudělal. Nelze se tak ubránit dojmu, že také velikost volebního obvodu hraje svou roli při postupu a důkladnosti soudního přezkumu. Jinak řečeno, v prrípadě malého počtu hlasů jsou volební soudy nakloněny provést přepočet hlasů i v př́padě nekonkrétních podežrení, nicméně u značného počtu hlasů (typicky volby do statutárních měst) takový přepočet neprovádějí - byl by totiž extrémně pracný.

V našem výzkumu jsme konečně také sledovali (pokud jsme to byli z odůvodnění schopni identifikovat), kdy soudy přistupovaly $\mathrm{k}$ úplnému přepočtu všech hlasů (takových případů bylo celkem 15) a kdy pouze k částečnému (11). Částečný přepočet může spočívat jen $v$ přepočtu hlasů $v$ určitém okrsku(cích), v přepočtu hlasů pro konkrétní stranu ${ }^{70}$ nebo jen v přepočtu rozdělení mandátů (nikoliv samotných hlasů). Poslední z variant často následuje po přepočtu hlasů či identifikování jiného problému (např. absence trvalého pobytu kandidáta v obci) jako kontrola, zda rozdílný výsledek (součet) hlasů může vést také k přerozdělení či jinému obsazení mandátů v zastupitelstvu - jinak totiž netřeba přistupovat ke změně vyhlášených volebních výsledků. ${ }^{71}$

67 Usnesení Krajského soudu v Brně ze dne 6. 11. 2018, č. j. 63 A 5/2018-77, či ze dne 8. 11. 2018, č. j. 63 A 9/2018-48.

$68 \mathrm{~V}$ ostatních případech přepočtů nebylo možné na základě odůvodnění tento parametr jednoznačně určit.

69 Srov. usnesení Krajského soudu v Brně ze dne 6. 11. 2018, č. j. 63 A 5/2018-77 a č. j. 63 A 4/2018-101.

70 Např. usnesení Krajského soudu v Brně ze dne 5. 11. 2018, č. j. 63 A 4/2018-101.

71 Např. usnesení Městského soudu v Praze ze dne 5. 11. 2018, č. j. 14 A 216/2018-33, v jehož př́ípadě byl Český statistický úřad požádán o vypracování modelu volebního výsledku, z něhož vyplynulo, že by nedošlo k přerozdělení mandátů ani změně pořadí zvolených kandidátů. 


\section{Neplatnost hlasování}

V roce 2018 bylo podáno 44 návrhů čistě na neplatnost hlasování, 33 návrhů na neplatnost hlasování v kombinaci s návrhem na neplatnost voleb, 11 návrhů na neplatnost hlasování v kombinaci s návrhem na neplatnost volby kandidáta(ů) a ve 12 prŕpadech byla podána kombinace všech tř́ druhů návrhů. Celkem tedy byla neplatnost hlasování požadována v přibližně $41 \%$ př́padů. Úspěšně se navrhovatelé domohli vyslovení neplatnosti hlasování ve dvou př́padech.

\subsection{Typologie vad namítaných v návrzích na neplatnost hlasování}

Již v minulém článku jsme vymezili, že vady vedoucí k úspěchu návrhu na neplatnost hlasování by měly spočívat ve skutečnostech, které vyvolají zásadní pochybnosti o jeho správnosti ${ }^{72}$ - soud tedy musí nabýt důvodného přesvědčení o tom, že nelze s jistotou určit, zda (ověřitelné) výsledky volebního hlasování skutečně odpovídají vưli voličů. Jinými slovy, tyto vady by se měly týkat samotného aktu hlasování a zjišt’ování volebních výsledků ${ }^{73}$ a musí svědčit o tom, že s výsledky bylo nepř́pustně manipulováno takovým způsobem, který zcela zpochybňuje jejich důvěryhodnost. ${ }^{74}$ Nadto by tato manipulace měla vést $\mathrm{k}$,faktickému hrubému ovlivnèni výsledku blasováni“.

Fakticita ovlivnění je dle nás v těchto prrípadech ovšem požadavek poměrně obtížně prokazatelný. Zatímco o nepř́ípustné manipulaci s výsledky hlasování musí být soud s jistotou přesvědčen, je otázkou, zda stejný požadavek vztahovat i na zjištění zcela konkrétního ovlivnění těchto výsledků v průběhu hlasování. Ovlivnění výsledků totiž dle našeho názoru bude $\mathrm{v}$ těchto případech již z povahy věci možné s větší či menší mírou pravděpodobnosti pouze odhadovat. Dle našeho závěru by význam této podmínky měl spočívat spíše v „odfiltrování“ vad, které by podle posouzení jejich intenzity mohly mít na výsledek hlasování pouze marginální (popř. žádný) vliv. Vady vedoucí k závěru o manipulaci s výsledky hlasování mohou spočívat v různých druzích pocbybeni ze strany okerskové volebni komise [ovšem nikoliv v nesprávném sčítání hlasů nebo nesprávném vyhodnocení (ne)platnosti hlasů - tyto vady lze zhojit kontrolou hlasů, tj. v rámci řízení o návrhu na neplatnost volby kandidáta(ů)], popř́padě v úmyslném manipulování s výsledky hlasování př́imo okrskovou volební komisí.

72 FERFECKÝ, Jan, Jan SCHEUER a Josef ŠÍP. Volby do obecních zastupitelstev 2018 - analýza volební judikatury krajských soudů. Casopis pro právní védu a praxi, 2020, č. 1, s. 71-94, s. 93 a 94 . Dostupné z: https://journals.muni.cz/cpvp/article/view/12592 [cit. 16. 12. 2020].

73 Srov. POTĚŠIL, Lukáš a kol. Soudní rád spráuní: komentár. Praha: Leges, 2014, s. 835-837.

74 Právě charakter namítané manipulace je klíčový. Pro ilustraci lze uvést, že např́klad úmyslné nezapočítávání platných hlasů bude vada odstranitelná přepočtem hlasů (řízení o neplatnosti volby kandidáta), nicméně úmyslné „zneplatňování“ hlasů bude zpochybňovat důvěryhodnost výsledků jako celku (půjde o neplatnost hlasovánî). Pod pojmem „manipulace“ proto v této kapitole rozumíme pouze druhý popsaný význam. 
Z naší analýzy za rok 2018 vyplynulo, že volebním okrskovým komisím byla poměrně často vytýkána nepřípustná manipulace s výsledky v pribęhu hlasováni do prénosné volební schránky. To svědčí o tom, že tato část hlasování je ze strany navrhovatelů vnímána jako náchylnější k možnému zneužití (v jednom prrípadě se ostatně jednalo o výtku důvodnou, o čemž bude pojednáno podkapitole 5.2), vzhledem k tomu, že probíhá pod dohledem pouze několika (dvou) členů okrskové volební komise ( $\int 33$ odst. 7 zákona o volbách do obecních zastupitelstev). Okrskovým volebním komisím lze proto doporučit, aby pečlivě dbaly na transparentnost celého tohoto procesu (včetně výběru vyslaných členů) a vyvarovaly se tak př́padným nařčením z vytváření prostoru pro manipulaci.

Ve vztahu k tomuto typu vad upozorňujeme rovněž na závěr soudu o tom, že opakované návštervy s přenosnou volební schránkou u stejného voliče nejsou v rozporu se zákonem (ač se jedná o praxi nestandardní - v tomto př́ípadě došlo ke třem návštěvám, přičemž při první volič nehlasoval, při druhé vyžádané návštěvě nebylo členům volební komise otevřeno a hlasoval až při třetí návštěvě na jeho opakovanou žádost). ${ }^{75}$

Zopakujme, že i v prípadě manipulace s volebními výsledky navrhovatel samozřejmě musí unést souvisejici dỉkazni bremeno, přičemž o této manipulaci nesvědčí sama o sobě námitka poukazující na složení okrskové volební komise pouze ze zástupců konkurenčních volebních stran, popř. jejich sympatizantů. Př́ležitost k delegaci svého člena má totiž každá účastnící se volební strana (『 17 odst. 2 zákona o volbách do obecních zastupitelstev).$^{76} \mathrm{I} \mathrm{v}$ tomto typu řízení soudy tvrzení navrhovatelů o manipulaci s výsledky konfrontují primárně se zápisem o průběhu a výsledku hlasování, poprípadě s výslechem členů okrskové volební komise, což odpovídá postavení okrskové volební komise, která je zákonným garantem řádného průběhu hlasování. Garance zákonnosti hlasování do přenosné volební schránky je primárně dána př́itomností členů okrskové volební komise s touto schránkou vyslaných, což soud zdůraznil ve věci namítané manipulace při hlasování v domově pro seniory. ${ }^{77}$

Dále lze upozornit na vytýkanou manipulaci s výsledky v prỉběbu sčitáni hlasů. V konkrétním př́padě byla tato manipulace dovozována ze skutečnosti, že se dvě členky uzavřely při sčítání do odlišné místnosti, přičemž ostatním členům hrubým způsobem bránily ve vstupu. Soud v tomto prrípadě na základě výkladu zákona uzavřel ${ }^{78}$, že sčítání v odlišných místnostech představuje selhání kontrolních mechanismů. Ovšem vzhledem $\mathrm{k}$ tomu, že takto postupovala celá okrsková volební komise, s tímto postupem všichni členové souhlasili a bylo vyvráceno tvrzení o odpírání vstupu do místnosti, soud neshledal vliv této vady na výsledky hlasování.

\footnotetext{
75 Usnesení Krajského soudu v Brně ze dne 8. 11. 2018, č. j. 64 A 16/2018-205.

76 Usnesení Krajského soudu v Ústí nad Labem - pobočka v Liberci ze dne 6.11. 2018, č. j. 64 A 21/2018-113.

77 Usnesení Krajského soudu v Ústí nad Labem - pobočka v Liberci ze dne 2. 11. 2018, č. j. 64 A 16/2018-134.

78 Usnesení Krajského soudu v Ostravě - pobočka v Olomouci ze dne 7. 11. 2018, č. j. 58 A 3/2018-105.
} 
Další vady, se kterými se soudy hojně setkávaly, měly svůj původ ve vžtaziçch mez̧i členy okerskové komise (např. tvrzená „šikana“ jednoho z členů komise ${ }^{79}$, opakované rozmluvy starostky obce s členy komise ${ }^{80}$ ), přičemž jim je povětšinou společné, že tento typ vad zpravidla nemá žádný kauzální vztah k výsledkům hlasování, resp. nijak nesvědčí ani o nepř́ípustné manipulaci s výsledky. K počtu vydaných a odevzdaných obálek se soud vyjádřil $\operatorname{tak}^{81}$, že malý rozdíl mezi počtem vydaných a odevzdaných úředních obálek žádné podezření z manipulace s výsledky nezakládá, nicméně jiná situace by byla, kdyby byl mezi počtem vydaných a odevzdaných obálek výrazný rozdíl, nebo kdyby počet odevzdaných obálek převyšoval počet vydaných obálek.

Další typ vytýkaných vad je možné obecně označit jako „pochybeni““ okrskové volební komise, přčemž výtky směřovaly zejména $\mathrm{k}$ deficitưm $u$ zabezpečení volebních uren, popř. volebních místností. ${ }^{82}$

\subsection{Př́pady vyslovení neplatnosti hlasování}

V této podkapitole přiblížíme dva prípady, ve kterých soud prohlásil hlasování za neplatné, přičemž v obou případech vycházel z provedeného dokazování.

V první věci ${ }^{83}$ soud dospěl ke skutkovému závěru, že bylo hlasováno i za občany, kteří se voleb nezúčastnili, a to prostřednictvím přenosné volební schránky. Dokonce zjistil i to, že bylo vytvářeno více verzí vyplněných seznamů voličů, které měly nezákonný postup zakrýt. Soud opakovaně zdůraznil, že nebylo možné prokázat, které subjekty měly z tohoto postupu prospěch, i přesto považoval za nutné prohlásit hlasování za neplatné, jelikož k zásadnímu porušení zákona došlo s vědomím (některých) členů okrskové volební komise. Zároveň ovšem poukázal na to, že v daném př́padě by ve výsledku hlasování udělaly rozdíl i 4 (plné) hlasovací lístky, přičemž na základě dokazování měl za to, že k „falešnému“ hlasování došlo minimálně v 7 prrípadech. Soud rovněž označil za neprrípustnou praxi, kdy je s přenosnou volební schránkou vzato více úředních obálek a hlasovacích lístků, než je počet občanů, kteří si o možnost volby touto cestou požádali. Pro zajímavost dodáváme, že v jiném př́padě (jiný) soud ${ }^{84}$ ve skutečnosti, že do přenosné volební schránky prokazatelně hlasovala osoba, která si o tuto možnost nepožádala, nespatřoval porušení zákona za podmínky, že nebylo zabráněno hlasovat jiným voličům, kteří na hlasování do přenosné urny měli zákonný nárok. Oba uvedené názory se dle nás částečně vylučují (zásoba větším počtem obálek a hlasovacích lístků je předpokladem, aby do přenosné volební urny mohly hlasovat i osoby, které si o tuto možnost nepožádaly).

\footnotetext{
79 Usnesení Krajského soudu v Praze ze dne 7. 11. 2018, č. j. 43 A 141/2018-82.

80 Usnesení Krajského soudu v Ostravě - pobočka v Olomouci ze dne 7. 11. 2018, č. j. 58 A 3/2018-105.

81 Usnesení Krajského soudu v Praze ze dne 7. 11. 2018, č. j. 43 A 141/2018-82.

82 Usnesení Krajského soudu v Českých Budějovicích ze dne 2. 11. 2018, č. j. 52 A 12/2018-60.

83 Usnesení Krajského soudu v Praze ze dne 6. 11. 2018, č. j. 51 A 9/2018-176.

84 Usnesení Krajského soudu v Brně ze dne 8. 11. 2018, č. j. 64 A 16/2018-205.
} 
V řízení o druhém úspěšném návrhu ${ }^{85}$ soud dospěl k tomu, že volební schránka, volební místnost i volební dokumenty nebyly náležitě zabezpečeny, volební schránku bylo možné bez porušení pečeti otevrrít a ve volební místnosti zůstaly mezi dvěma volebními dny volně prrístupné hlasovací lístky a jiná dokumentace. V tomto řízení navíc vystupovalo 35 navrhovatelů, kteří k návrhu přiložili čestná prohlášení, z nichž vyplývalo, že jejích hlasy nebyly do výsledků započítány. V kontextu dalších zjištěných informací tedy byl průběh hlasování zpochybněn. Soud výslovně uvedl, že „výsledky hlasováni s vysokou mírou pravděpodobnosti nemusí odpovídat viili voličư". Jak je zřejmé i z této citace, soud se nijak nevěnoval fakticitě ovlivnění výsledků a rozhodl na základě předpokladu.

Z výše uvedeného můžeme usuzovat na to, že pro soud bude zpravidla obtížné s jednoznačnou jistotou konstatovat, že zjištěná manipulace výsledky hlasování skutečně hrubě ovlivnila. Nicméně lze vyslovit závěr, že tento typ návrhu bude mít větší šanci na úspěch, pokud budou výsledky hlasování spíše těsné.

\section{Volební kampaň a neplatnost voleb}

Návrh na neplatnost voleb jako jeden ze tří možných návrhů následného přezkumu voleb je v porovnání s návrhem na neplatnost hlasování a neplatnost volby kandidáta/ů návrhem „nejširším“, nebot' může vést ke zrušení voleb jako celku a opakování všech částí volebního procesu včetně vyhlášení nového data voleb. Jde tedy o nejzávažnější protiprávnosti, které se váží k volbám jako celku. ${ }^{86}$

Konkrétně takovým závažným důvodem pro prohlášení voleb za neplatné může být konání voleb, byt' by se neměly vůbec uskutečnit, konaly by se v nesprávných volebních obvodech, nastala by vada způsobující to, že volby nebyly řádně vyhlášeny nebo by některá volební strana byla fakticky vyloučena $z$ volebního procesu. ${ }^{87}$ Posledním a nejčastějším důvodem pro neplatnost voleb jako celku je porušení pravidel volební kampaně. Z výčtu těchto možností je patrné, že jde o skutečnosti, které nastaly ještě před začátkem hlasování. $\mathrm{V}$ př́padě většiny důvodů pro neplatnost voleb je již z jejich samotného popisu jasné, proč je nutné prristoupit k takto radikálnímu kroku. U volební kampaně se pak vychází z premisy, že chyby ve volební kampani ovlivnily vưli voličů při utváření jejich voličské preference, pročež je nezbytné opakovat celý proces, aby vưle voličů mohla být znovu utvářena. V rámci soudního přezkumu komunálních voleb 2018 bylo podáno celkem 63 návrhů čistě na neplatnost voleb (28 \% všech př́ípadů), dále 33 návrhů kombinujících neplatnost voleb a hlasování (14\% všech př́padů), 16 návrhů kombinujících požadavek na neplatnost voleb a volby určitého kandidáta (7 \% všech př́ipadů) a konečně 12 návrhů kombinujících všechny tři druhy návrhů (5\% všech případů).

\footnotetext{
85 Usnesení Krajského soudu v Českých Budějovicích ze dne 14. 11. 2018, č. j. 52 A 7/2018-87.

86 Srov. usnesení Městského soudu v Praze ze dne 5. 11. 2018, č. j. 14 A 216/2018-33.

87 Ibid.
} 
Vzhledem k tomu, že vyjma volební kampaně se v rámci soudního přezkumu komunálních voleb v roce 2018 nevyskytuje jakýkoliv jiný důvod pro prohlášení neplatnosti voleb, soustředíme se v další části textu výhradně na volební kampaň. Tu je nutné vnímat jako nezbytný nástroj politických subjektů ucházejících se o hlasy voličů, v rámci níž mohou činit celou řadu aktivit s cílem přesvědčit voliče odevzdat svůj hlas právě pro tento subjekt či kandidáta tohoto subjektu.

Zákon o volbách do obecních zastupitelstev upravuje volební kampaň pouze v ustanovení $\int 30$ a to jen ve třech odstavcích. Ve stručnosti lze shrnout, že tento zákon umožňuje vést volební kampaň na starostou vyhrazených plochách, z hlediska jejich využití však musí být dodržen princip rovnosti kandidujících subjektů, tj. tyto subjekty musí mít rovné podmínky pro př́stup k těmto plochám. Současně je také v př́padě obecních voleb zakotveno třídenní volební moratorium týkající se volebních průzkumů a zákaz volební agitace a propagace ve volební místnosti a jeho okolí.

Současně nelze zpochybňovat, že volební kampaň je jedním z aspektů hodnocení rádně prováděných svobodných a demokratických voleb, přičemž její čestné a poctivé vedení je ztotožňováno s tzv. čistotou voleb. Volební agitace nesmí přesahovat určité intenzity přecházející v teror. ${ }^{88}$ Za závažnější porušení pravidel volební kampaně bývají považována ta porušení, která se odehrají v posledních dnech volební kampaně, nebot' právě v tomto období docházî k rozhodování nerozhodnutých voličů o tom, komu ve volbách odevzdají hlas.

V zásadě lze kategorizovat vady směřující na porušení volební kampaně do dvou skupin vady proti obsahu volební kampaně (t). typicky směřující proti tomu, co bylo kým ve prospěch někoho či proti někomu v průběhu volební kampaně tvrzeno) a vady proti rozsahu volební kampaně (tj. proti prostředkům, které ve volební kampani byly či mohou být použity). Příkladně pak za vážné porušení volební kampaně bylo shledáno tzv. obchodně tržní pojetí voleb, tj. podplácení voličů (finančním slibem voličům za odevzdání hlasu určitému politickému subjektu). ${ }^{89}$ Nebyl jím však považován slib vstupu a konzumace na povolební party některým voličům $\mathrm{v}$ př́padě hlasu pro jednu z kandidujících stran..$^{0}$

\subsection{Volby ve Strakonicích}

Z celkových 124 návrhů, které se dotýkají neplatnosti voleb jako celku, byl pouze jeden úspěšný návrh, který byl značně medializován a týkal se voleb ve městě Strakonice. Krajský soud v Českých Budějovicích ${ }^{91}$ prohlásil volby do Zastupitelstva města Strakonice konané

88 Ústavní soud v nálezu ze dne 26. 1. 2005, sp. zn. Pl. ÚS 73/04 (N 17/36 SbNU 185), tzv. kauza senátora Nádvorníka, vymezil „,teror“ dle prvorepublikového nálezu Volebního soudu ze dne 23. 4. 1926 jako něco, čímž se ,činí fyzický a psychický nátlak na volné rozhodnutí voličů tou měrou, že ani tajnost volby není s to, aby svobodné rozhodnutí voličovo zabezpečila.“

89 Nález Ústavního soudu ze dne 18. 1. 2011, sp. zn. Pl. ÚS 57/10, N 2/60 SbNU 11.

90 Nález Ústavního soudu ze dne 10. 2. 2015, sp. zn. III. ÚS 3673/14.

91 Usnesení Krajského soudu v Českých Budějovicích ze dne 20. 11. 2018, č. j. 52 A 16/2018-195. 
ve dnech 5. a 6. 10. 2018 za neplatné, právě z důvodu porušení pravidel volební kampaně. Rada města (složená převážně ze zástupců jednoho z kandidujících subjektů - Strakonická veřejnost) před konáním komunálních voleb zakázala politickou propagaci v místním zpravodaji a výlep materiálů na plakátovacích plochách města. Samotná Strakonická veřejnost přitom ke kampani využívala sloupy veřejného osvětlení, které jí byly pronajaty Odborem dopravy Městského úřadu Strakonice. Navíc krajský soud identifikoval v průběhu volebního období postupnou snahu omezení výlepových ploch, jakož i omezení dalších prostředků, které opoziční subjekty mohly ke své prezentaci využívat. S ohledem na všechny zjištěné skutkové okolnosti považoval krajský soud uvedené jednání za rozporné se základním demokratickým principem volné, rovné a svobodné soutěže politických stran.

Po přečtení celého odůvodnění a při znalosti relevantní volební judikatury lze tomuto rozhodnutí vytknout několik skutečností. Celé usnesení je psáno poměrně útočně vůči dosavadnímu vedení města, přičemž jsou hodnoceny kroky vedení tohoto města $\mathrm{v}$ průběhu celého volebního období, nikoliv jen v období po vyhlášení komunálních voleb. ${ }^{92}$ Soud zohlednil také skutečnosti, které nastaly až po podání návrhu na neplatnost voleb. Především se ale krajský soud pouze velmi stručně zabýval otázkou hrubého ovlivnění výsledku voleb.

Právě tato otázka byla také krajskému soudu vytknuta $\mathrm{v}$ rámci řízení o ústavní stížnosti, proto Ústavní soud dané usnesení zrušil. ${ }^{93}$ Ztotožnil se s konstatováním porušení zákona o volbách do obecních zastupitelstev, jakož i nezpochybnil souvislost mezi volební vadou a volebním výsledkem. Za nedostatečný však považoval závěr ohledně toho, „zda došlo ke hrubému ovlivnèni výsledku, tj. zda by byly mandáty rozděleny jinak, pokud by k. vadám nedošlo. Zde krajský soud jednak nesprávnè uplatñuje princip potenciálni kauzality, keterý již byl volebnim zákonem opustèn, jednak vycházi toliko z informace o celostátním primèru nerozhodnutých voliču a počtu blasiu chybèjicich politickým uskupenim k prekeročeni $5 \%$ uzavíraci klauzule a tím k prìdèleni mandátu. Krajský soud tedy skutková zjistèni hodnotil pomoci nižši miry drik.azu, než kterou zákonodárce ve volebním zákoně pro rízeni préd volebnimi soudy stanovil. "Navíc krajský soud nezohlednil ani panašování, které je pro komunální volby typické.

V navazujícím řízení krajský soud volby do Zastupitelstva města Strakonice opětovně prohlásil za neplatné, přičemž odůvodnění doplnil v intencích nálezu Ústavního soudu. ${ }^{94}$ Na podkladě řady matematických výpočtů uzavřel, že „výżnamné żmèny v rozdělení mandátů (až pètina mandátů) by byly možné na základè minimálních presunů počtu blasü " a že omezení volební kampaně ze strany Strakonické veřejnosti mělo hrubý vliv na volební výsledek.

92 Na tomto místě jen připomínáme, že volební kampaň je dle zbývajících volebních zákonů definována jako časový úsek od vyhlášení voleb ve Sbírce zákonů po zveřejnění celkových výsledků voleb ve Sbírce zákonů. Přesto krajský soud posuzoval i události, které se odehrály před vyhlášením voleb, nebot' kroky stávajícího vedení města $\mathrm{v}$ průběhu celého volebního období mohou mít vliv na podobu vedené volební kampaně v následujících volbách.

93 Nález Ústavního soudu ze dne 2. 4. 2019, sp. zn. I. ÚS 4178/18.

94 Usnesení Krajského soudu v Českých Budějovicích ze dne 17. 5. 2019, č. j. 52 A 16/2018-310. 
I proti druhému usnesení krajského soudu byla podána ústavní stížnost, která byla odmítnuta ${ }^{95}$ (de facto tak bylo zrušení voleb ve Strakonicích potvrzeno), jelikož krajský soud dle Ústavního soudu postupoval v souladu se závazným právním názorem a své závěry jasně, srozumitelně, logicky a přesvědčivě odůvodnil. Upozornit lze na disentnî stanovisko prof. Filipa, který upozorňuje na atypičnost rozsáhlých matematických a statistických výpočtů ze strany krajského soudu a připomíná značný časový prostor, který měl krajský soud na učinění svých závěrů v dané věci. Přitom při běžném přezkumu voleb, který má být ideálně skončen do 20 dnů ode dne dojití návrhu, krajské soudy nemají tento časový prostor, aby mohly přistoupit k takto důsledným matematickým a statistickým výpočtům. Stejně tak je připomenuta i absence politologického vzdělání u řady rozhodujících soudců.

\subsection{Neúspěšné návrhy}

Volby ve Strakonicích však nebyly jediným př́padem, v němž krajské soudy posuzovaly volební kampaň ve vztahu k případnému prohlášení neplatnosti voleb. Vzhledem k poměrně velkému množství návrhů na neplatnost voleb však upozorníme pouze na některé př́pady.

Obsahově se volbám ve Strakonicích alespoň trochu blíží přezkum voleb do zastupitelstva městského obvodu Ostrava-Poruba a současně do zastupitelstva Ostravy. ${ }^{96}$ Navrhovatel zde tvrdil porušení volební kampaně spočívající v nevybírání místních poplatků za zábor veřejného prostranství (využitého k volební kampani), nelegální využívání billboardů ve volební kampani či využívání sloupů veřejného osvětlení a staveb technické infrastruktury $\mathrm{k}$ volební kampani, byt' takové použití ohrožuje bezpečnost silničního provozu. Nicméně krajským soudem nebylo shledáno porušení volebního zákona, jelikož navrhovatel konkrétně neuvedl, které subjekty a jak konkrétně měly být poškozeny porušením pravidel volební kampaně.

Obdobně jako v případě Strakonic došlo k porušení pravidel volební kampaně ${ }^{97} \mathrm{v}$ př́ipadě voleb do zastupitelstva obce Hodkovice nad Mohelkou. ${ }^{98}$ Zde se jednalo o nedovolenou agitaci v okolí volební místnosti. Před budovou školy (jediná volební místnost v obci) stál automobil s nápisem namířeným na jednoho z kandidátů $\mathrm{v}$ daných volbách (v časovém rozpětí zhruba od 16:00 do 17:45). Nejednalo se však o porušení takovým způsobem, který by hrubě ovlivnil výsledky voleb. Kandidát, vưči němuž nápisy na automobilu směřovaly, byl do zastupitelstva obce zvolen, jeho volební strana výsledky voleb nezpochybňovala a toto porušení pravidel volební kampaně nemohlo ovlivnit více než

\footnotetext{
95 Usnesení Ústavního soudu ze dne 9. 8. 2019, sp. zn. IV. ÚS 1767/19.

96 Usnesení Krajského soudu v Ostravě ze dne 30. 10. 2018, č. j. 21 A 14/2018-17.

97 Konkrétně se jednalo o porušení \30 odst. 3 zákona o volbách do obecních zastupitelstev.

98 Usnesení Krajského soudu v Ústí nad Labem - pobočka v Liberci ze dne 2. 11. 2018, č. j. 64 A 12/2018-22.
} 
jednotky voličů. Na základě rozebíraného rozhodnutí lze dle našeho názoru zobecnit, že porušení volební kampaně směřující proti konkrétnímu kandidátovi či volební straně se tak může domáhat pouze takto „poškozenýc kandidát nebo volební strana.

Ve volbách do Městské části Praha $22^{99}$ byla „volebni kampaň (...) vedena formou zuverejňováni zavádèjicich informaci o kandidátech zúčastnènjich volebnich stran, coそ̌jjsou symptomy nečestné a nepoctivé volebni kampaně". Avšak v takové volební kampani nebylo shledáno porušení \30 zákona o volbách do zastupitelstev obcí, jelikož toto ustanovení neobsahuje zákaz vedení nečestné a nepoctivé volební kampaně. Dle našeho názoru však Městský soud v Praze nepřhlédl k pravidlům volební kampaně, které byly vyvozeny výše citovanou judikaturou, $\mathrm{v}$ důsledku čehož by bylo nutné $\mathrm{v}$ dané věci posuzované jednání posoudit jako porušení pravidel volební kampaně (tj. první krok algoritmu volebního přezkumu by byl shledán za naplněný). Dále se pak měl podle nás městský soud zabývat vlivem této nezákonnosti na volební výsledek a potencialitou hrubého ovlivnění tohoto výsledku. Nerespektování citovaného algoritmu přezkumu voleb lze přitom shledat také $\mathrm{v}$ dalších rozhodnutích krajských soudů. ${ }^{100} \mathrm{Na}$ druhé straně je nutné uvést, že se městský soud v citovaném usnesení zabýval rovněž tím, zda namítaná vada a aplikované ustanovení \30 zákona o volbách do obecních zastupitelstev není v rozporu s ústavním pořádkem. Ostatně právě na tento aspekt upozornil Ústavní soud, který pro zjevnou neopodstatněnost odmítl ústavní stížnost směřující právě proti tomuto usnesení městského soudu. ${ }^{101}$ V rámci judikatury krajských soudů se bylo možné setkat též s př́pady, kdy krajské soudy konstatovaly absenci tvrzení o tom, jak určitá volební vada měla vliv na zjištěný výsledek voleb. ${ }^{102}$ Lze také dohledat prípady, v nichž krajské soudy konstatovaly absenci tvrzení navrhovatele o porušení právních předpisů upravujících volby a současně absenci tvrzení o hrubém ovlivnění výsledků voleb v důsledku takového porušení právních předpisů. ${ }^{103}$ I z výše rozebíraných př́padů lze seznat, že se soudy drží jednoho ze základních pravidel pro přezkum voleb - volební výsledek odpovídající vưli voličů. K prohlášení voleb za neplatné, což vede k opakování celého volebního procesu (od fáze vyhlášení voleb až po fázi vyhlášení výsledků voleb), přistupují zcela výjimečně. Od častějšího prohlášení voleb za neplatné navíc může odradit i „strakonická zkušenost“", kdy v podstatě volební strana, která dle krajského soudu měla z jednotlivých porušení pravidel volební kampaně profitovat, dosáhla v opakovaných volbách ještě většího volebního výsledku.

99 Usnesení Městského soudu v Praze ze dne 31. 10. 2018, č. j. 8 A 155/2018-59.

100 Usnesení Krajského soudu v Ostravě ze dne 25. 10. 2018, č. j. 21 A 13/2018-6, či usnesení Krajského soudu v Ústí nad Labem ze dne 30. 10. 2018, č. j. 40 A 14/2018-65.

101 Usnesení Ústavního soudu ze dne 20. 11. 2018, sp. zn. II. ÚS 3702/18.

102 Např́iklad usnesení Krajského soudu v Ostravě ze dne 22. 10. 2018, č. j. 24 A 19/2018-7, nebo usnesení Krajského soudu v Ústí nad Labem ze dne 6. 11. 2018, č. j. 40 A 34/2018-27.

103 Usnesení Krajského soudu v Hradci Králové - pobočka v Pardubicích ze dne 7. 11. 2018, č. j. 52 A 126/2018-13. 
V př́istupu krajských soudů lze shledat i jisté rozdíly - zejména do jaké míry berou v potaz judikaturou dovozený algoritmus přezkumu voleb a naplnění všech tř́ podmínek. K rozdílům zřejmě přispívá i velmi strohá zákonná úprava volební kampaně v zákoně o volbách do obecních zastupitelstev. Současně ze strany krajských soudů nedocházelo př́liš k reflexi vymezení volební kampaně v jiných volebních zákonech, zatímco hojně bylo upozorněno na změnu zákonné úpravy týkající se přezkumu voleb - jazykové formulace „mohl ovlivnit výsledky voleb“ na „hrubě ovlivnil výsledky voleb“, což i dle krajských soudů vedlo ke zpřísnění požadavků na existenci volební vady, pro kterou by volby byly prohlášeny za neplatné.

\section{Závěr}

V prríspěvku jsme svou pozornost upřeli zejména na meritorní stránku soudního přezkumu, tj. zabývali jsme se důvody, na základě nichž soudy přistoupí k prohlášení neplatnosti volby kandidáta/ůn, neplatnosti hlasování či neplatnosti voleb jako celku. $\mathrm{K}$ tomu bylo nezbytné rozebrat otázku dokazování ve volebním soudnictví, existenci zvlášt' významné indicie, charakterizovat také roli volební komise pro soudní přezkum voleb či vymezit pojem volební kampaň a její náležitosti.

I na př́kladu voleb v roce 2018 je patrné, že nejméně úspěšným návrhem byl návrh na neplatnost voleb jako celku, nebot' se jedná o největší zásah do vůle voličů - je totiž opakován celý volební proces; zatímco nejvíce úspěšné byly návrhy na prohlášení neplatnosti volby kandidáta/ů. Konkrétní počty, i ve vztahu k jednotlivým krajským soudům a jejich pobočkám, lze nalézt v tabulce zařazené ve druhé kapitole tohoto článku. Celková úspěšnost návrhů se pohybuje kolem $5 \%$, na čemž se podílí i značná obecnost a spekulativnost námitek obsažených ve většině návrhů.

Pokud už soud k zásahu přistoupil, jednalo se nejčastěji o rozhodnutí o neplatnosti volby kandidáta (tj. o změnu volebních výsledků). V této souvislosti je klíčovým nástrojem soudu přepočet hlasů či rozdělení mandátů. Na diskutovaných př́ikladech jsme znázornili, že k přepočtu hlasů přistupují soudy zásadně na základě vyvstalých indicií, jež musî mít patřičnou intenzitu. Tyto indicie jsou do značné míry kazuistické, nicméně lze říci, že klíčovou roli hrají okrskové volební komise a obsah jejich konečného zápisu, z něhož lze samozřejmě identifikovat možná podezření o řádném průběhu hlasování a sčítání hlasů. Jako určitý problém ovšem vidíme situace, kdy soudy přistupovaly $\mathrm{k}$ přepočtu hlasů zcela arbitrárně, aniž by identifikovaly konkrétní podežrení o správnosti volebních výsledků. $\mathrm{K}$ zamyšlení jistě mohou být rovněž značné rozdíly v poměru př́ípadů přepočtu k celkovému počtu věcí mezi krajskými soudy; zde zmiňujeme zejména velký počet přepočtů provedených u Krajského soudu v Brně.

I ve vztahu k neplatnosti hlasování lze ve zkoumané judikatuře vysledovat akcent na klíčový význam okrskové volební komise a zápisu o průběhu voleb. Zvláštní pozornost 
by ze strany okrskové volební komise měla být věnována i transparentnímu průběhu hlasování do přenosné volební urny, jelikož námitky navrhovatelů do této části hlasování často směřují (ostatně v jednom př́padě vedly v roce 2018 k vyslovení neplatnosti hlasovánî). Požadavek, aby došlo k faktickému hrubému ovlivnění voleb, je v řízení o neplatnosti hlasování z našeho pohledu poměrně nejasný. Aby soud vyhověl tomuto typu návrhu, musí totiž dospět k závěru, že výsledky hlasování byly zmanipulovány takovým způsobem, který v zásadě neni možné exaktně vymeziit (oproti situacím, které by mohl sám napravit prostřednictvím přepočtu v řízeních o neplatnosti volby kandidáta). Striktní trvání na průkazném faktickém ovlivnění výsledku hlasování by dle našeho názoru učinilo tento typ řízení v podstatě naprosto zbytečným, jelikož prokázání této fakticity bude z povahy věci spíše vyloučeno. Proto se domníváme, že v tomto typu řízení soud bude muset i nadále vycházet spíše z důvodného předpokladu vlivu na výsledek hlasování (ostatně v jednom případě vyslovení neplatnosti hlasování v roce 2018 tomu tak bylo). Lze však vyslovit, že tomuto důvodnému předpokladu budou nasvědčovat zejména situace, kdy byly výsledky voleb těsné.

$\mathrm{V}$ případě návrhů na neplatnost voleb jako celku (z důvodu porušení pravidel volební kampaně) byl pouze jediný návrh úspěšný, a i tento návrh musel podstoupit náročnou soudní cestu v podobě dvojího řízení u krajského i Ústavního soudu, která byla zpơsobena především splněním podmínky „došlo k faktickému ovlivnění výsledkư“. Navíc i přes veškerou snahu krajského soudu o zdůvodnění této podmínky se nelze ubránit dojmu, že se jednalo pouze o ,velmi podrobně zdůvodněný předpoklad“, který se zpětně ukázal (nejspíše) nedůvodným. Také na ostatních, neúspěšných, návrzích lze vidět, že i zjevná porušení pravidel volební kampaně (zejména nečestné či neférové vedení volební kampaně) nedosáhne dle výše uvedeného algoritmu přezkumu voleb takové závažnosti, aby toto porušení hrubě ovlivnilo výsledky daných voleb. To lze ilustrovat na případu voleb v obci Hodkovice nad Mohelkou, z něhož plyne i závěr, že v případě porušení pravidel dotýkajících se pouze určitého kandidáta či určité volební strany se návrhu na neplatnost voleb mohou domáhat pouze takto postižené subjekty. Současně by soudní přezkum volební kampaně usnadnilo bližší vymezení volební kampaně jako takové, ale především vymezení porušení pravidel volební kampaně (v podobě demonstrativního výčtu), která jsou považována za významná a mající (hrubý) vliv na výsledek voleb. V opačném případě totiž prohlášení neplatnosti voleb bude záležet na subjektivním vnímání soudního senátu stran porušení pravidel volební kampaně, na ochotě soudního senátu zabývat se skutečně podrobně potenciálním vlivem volební kampaně na výsledky voleb a zůstane tak spíše v rovině nahodilé kazuistiky než jasně stanovených pravidel.

Na samotný závěr považujeme za důležité upozornit na návrhy de lege ferenda vyslovené prrímo soudy, které navrhovaly např̀. zavedení namátkové kontroly výsledků voleb, případně následné kontroly volebním orgánem na žádost soudu ${ }^{104}$, či kontrolního přepočtu 
mimo soudní přezkum $\mathrm{v}$ případě těsných výsledků. ${ }^{105} \mathrm{Na}$ základě vlastní zkušenosti bychom $\mathrm{k}$ těmto návrhům přidali změnu ve vztahu k evidenci neplatných hlasů. V návrzích totiž často bývá argumentováno (podezřele) vysokým počtem neplatných hlasů, přičemž za stávající úpravy z výsledků voleb nelze odlišit, kolik hlasovacích lístků bylo skutečně neplatných a jaký počet hlasů představují pouze tzv. nevyužité hlasy. Evidence neplatných hlasů je přitom běžná u jiných typů voleb.

105 Usnesení Krajského soudu v Hradci Králové, pobočky Pardubice, ze dne 8. 11. 2018, č. j. 52 A 125/2018-37. 